\title{
A Recapitulation of Virology, Modes of Dissemination, Diagnosis, Treatment, and Preventive Measures of COVID-19: A Review
}

\author{
Viquar S. Shaikh, ${ }^{1}$ Gulam M. Nazeruddin, ${ }^{2}$ Yaseen I. Shaikh, ${ }^{2, *}$ Samir H. Bloukh, ${ }^{3}$ Zehra Edis ${ }^{3}$ and Habib M. Pathan ${ }^{4}$
}

\begin{abstract}
COVID-19, which is instigated by the severe acute respiratory syndrome coronavirus 2 (SARS-CoV-2), has caused the pandemic. This disease provoked with its epicenter in China. Belonging to the Coronaviridae family of viruses, it is a new strain of $\beta$ type of coronavirus. The World Health Organization (WHO) declared its name as 'SARS-CoV-2'. In January 2020, the WHO declared COVID-19 as the sixth public-health emergency of international suffering. Lack of etymology, precautionary measures, specified drug or vaccination for this viral infection was the main reason for the epidemic. Hence, there was an extensive need for the scientists throughout the globe to work on it. Some potential inhibitors have been reported to possibly treat COVID-19 affected patients. Likewise, a new technique, which is the Plasma Therapy, is used in the treatment. In this context, this review aims to summarize the epidemiology, virology, mode of dissemination, diagnosis, treatment, and prevention measures of COVID-19.
\end{abstract}

Keywords: COVID-19; SARS-CoV-2; Virology.

Received date: 11 May 2020; Accepted date: 26 May 2020

Article type: Review article

\section{Introduction}

The family Coronaviridae within the order of Nidovirales comprises the Coronaviruses. The viral coat of those viruses features a spike or $\mathrm{S}$ protein. As these viruses showed crown-like structure, they are named as Coronaviruses. Coronaviruses size is around $65-125 \mathrm{~nm}$, this is often the diameter size, and the genetic material is a single-stranded RNA having 26 to $32 \mathrm{kbs} .^{[1]}$ The Coronavirus family is split into 4 subgroups viz., alpha $(\alpha)$, beta $(\beta)$, gamma $(\gamma)$, and delta $(\delta)$ coronavirus. ${ }^{[2]}$ The viruses cause Severe Acute Respiratory Syndrome (SARS), pathogenic Influenza, and the Middle East Respiratory Syndrome (MERS), which can further cause acute lung injury (ALI) and acute respiratory distress syndrome (ARDS) that results in renal failure and ends up in death. ${ }^{[3]}$ Earlier it has been thought that these

\footnotetext{
${ }^{1}$ Department of Chemistry, NowrosjeeWadia College, Pune- 411 001, India ${ }^{2}$ Department of Chemistry, AbedaInamdar Sr. College, Pune- 411 001, India ${ }^{3}$ College of Pharmacy and Health Science, Ajman University, PO Box 346, Ajman, United Arab Emirates

${ }^{4}$ Advanced Physics Laboratory, Department of Physics, SavitribaiPhule Pune University, Pune-411 007, India

*E-mail: sheray2k@gmail.com (Y.Shaikh)
}

viruses only infect animals until the globe noticed the SARS outbreak caused by SARS-CoV in 2002 in Guangdong, China. ${ }^{[4]}$ After a decade, another pathogenic coronavirus, called Middle East respiratory syndrome coronavirus (MERS$\mathrm{CoV}),{ }^{[5]}$ caused the plague in Middle East countries. ${ }^{[6]}$

During December 2019, they reported many pneumonia patients with unidentified reasons behind the disease in Wuhan. After analyzing the sequence, the unidentified pneumonia was identified as a mutated strain of SARS-CoV, i.e., a unique coronavirus $(\mathrm{CoV})$, which was named as nCoV-2019. Novel Coronavirus 2019 caused the coronavirus disease 2019 (COVID-19). ${ }^{[7-9]}$ The virus may be a member of the $\beta$ subgroup of the family Coronaviridae. The nomenclature of the virus was done by the International Committee on Taxonomy of Viruses (ICTV) and was named as SARS-CoV-2 and the disease as COVID-19. ${ }^{[10]}$ Within the history, SARS-CoV (2003) had infected about 8098 individuals with a fatality rate of $9 \%$ across 26 countries throughout the globe. On the opposite hand, coronavirus (2019) infected 4618821 individuals till the date of this writing. It shows that the transmission rate of SARS-CoV-2 is on top of SARS-CoV. The genetic recombination event at 
$S$ protein within the Receptor Binding Domain(RBD) region of SARS-CoV-2 may be responsible for the enhanced transference ability of this virus. ${ }^{[11]}$ Further in this paper, we introduce the epidemiology, virology, transmission, pathogenicity, diagnosis, treatment of this infection, and the COVID-19.

\section{Epidemiology}

Transmission of virion depends on the source of the infection, the route by which it transmits, and the host of interest. The SARS and MERS are transmitted by animal intervened hosts (Paradoxurus hermaphrodites and Camelus dromedaries). ${ }^{[12]}$ Studies suggest that the primary host is pangolin ${ }^{[13]}$ and also bat. ${ }^{[14,15]}$ Earlier cases suggest the viral transmission from the seafood market in Wuhan, China. ${ }^{[16]}$ The secondary mode of transmission is person-to-person transmission as the major one. According to National health center (N.H.C.) of China, the disease COVID-19 can be transmited by inhaling droplets of saliva, by contact, through feces or by aerosol droplets too. ${ }^{[17]}$ Lack of data was responsible for the increase in the disease. Before the quarantine strategy was regulated and used, the disease was on a surge of massive destruction of mankind throughout China and the entire globe. Then it comes to the study of the Basic Reproductive rate $\left(R_{0}\right)$, whose definition states the mean several secondary cases ascribed by the first case after the case is introduced in a susceptible population. This $R_{0}$ is very important in predicting the pharmaceuticals and non-pharmaceuticals arbitrations. The threshold essential to get rid of the disease is calculated by $1-1 / R_{0}$. From this, we can conclude that if the threshold value is lower than eliminating, the disease becomes easy to be controlled by following the measures like quarantine, self-isolation, and lockdown. Social distancing can eradicate the influence of transmission. But if the threshold is high, then the population has to be subjected to medication or vaccination. ${ }^{[18]}$

As of May $18^{\text {th }}, 2020$ (Fig. 1), 4618821 cases of COVID-19 are confirmed according to the WHO report. ${ }^{[19]}$ The risk worldwide is high according to WHO. The top five countries (Table 1) are arranged based on their descending order of maximum infected cases and their mortality rates which have been calculated considering the population from the worldometer. ${ }^{[20]}$ As the pandemic originally observed in China, a controlled province is observed there. When the virus started spreading throughout the world, lack of knowledge regarding its diagnosis, its prevention, and its treatment led to a boost in the infected individuals in these top five countries as well as throughout the world. Delay in taking the precautionary steps is also one of the major reasons for the increase in infected individuals. China was successful in overcoming the rise of the epidemic by starting the anti-epidemic campaign. Quick quarantining was ordered for Wuhan and all the possible required resources were supported. As the epicenter of the epidemic was Wuhan, it was lockdown immediately, and no person was allowed to go out or come in. ${ }^{[21]}$ This quarantine step expanded from Wuhan to Hubei and then throughout the country. This immediate response strategy, which was successfully followed by each citizen in China, was the reason that China successfully came out of this devastating situation. The highest mortality rate per the given data is in Spain with 27650 death cases.

Table 1. Top 5 countries with a maximum confirmed case with deaths (Till 18 ${ }^{\text {th }}$, May 2020).

\begin{tabular}{cccc}
\hline Country & $\begin{array}{c}\text { Confirmed } \\
\text { Cases }\end{array}$ & $\begin{array}{c}\text { Total } \\
\text { Deaths }\end{array}$ & $\begin{array}{c}\text { Mortality Rate } \\
\text { (per1000/year) }\end{array}$ \\
\hline United States of America & 1432265 & 87180 & 0.0007 \\
Russian Federation & 290678 & 2722 & 0.0001 \\
United Kingdom & 243699 & 34636 & 0.0014 \\
Brazil & 233142 & 15633 & 0.0002 \\
Spain & 231350 & 27650 & 0.0016 \\
\hline
\end{tabular}

\section{Manifestation of COVID-19}

After clinical studies, we can state that various signs and symptoms of COVID-19 are summarized in Table 2:[22]

Table 2. Symptoms of COVID-19.

\begin{tabular}{ll}
\hline \multirow{2}{*}{ Initial symptoms } & Fever \\
& Coughing \\
& Muscle pain or fatigue \\
& Sore throat \\
& Heart palpitation \\
Lower frequency & Diarrhea \\
initial symptoms & Headache \\
& Loss of smell and taste \\
& $\begin{array}{l}\text { Shortness of breath and difficulty in breathing } \\
\text { Serious symptoms }\end{array}$ \\
& Loss of speech \\
& Chest pain \\
\hline
\end{tabular}

Maximum patients show a decrease in their white blood cell (WBC) count and many show lymphocytopenia.

\section{Gender and age group}

After analyzing various cases related to the patients of COVID-19, it is seen that the patients who are infected are adult patients. ${ }^{[23,24]}$ If we consider age, people of all ages can get infected by COVID-19. But mainly patients aged 70 and above get easily infected, as there is a decrease in immunity with an increase in age. ${ }^{[25]}$ Except elderly people, kids are also vulnerable to the infection of COVID-19. ${ }^{[26]}$ 


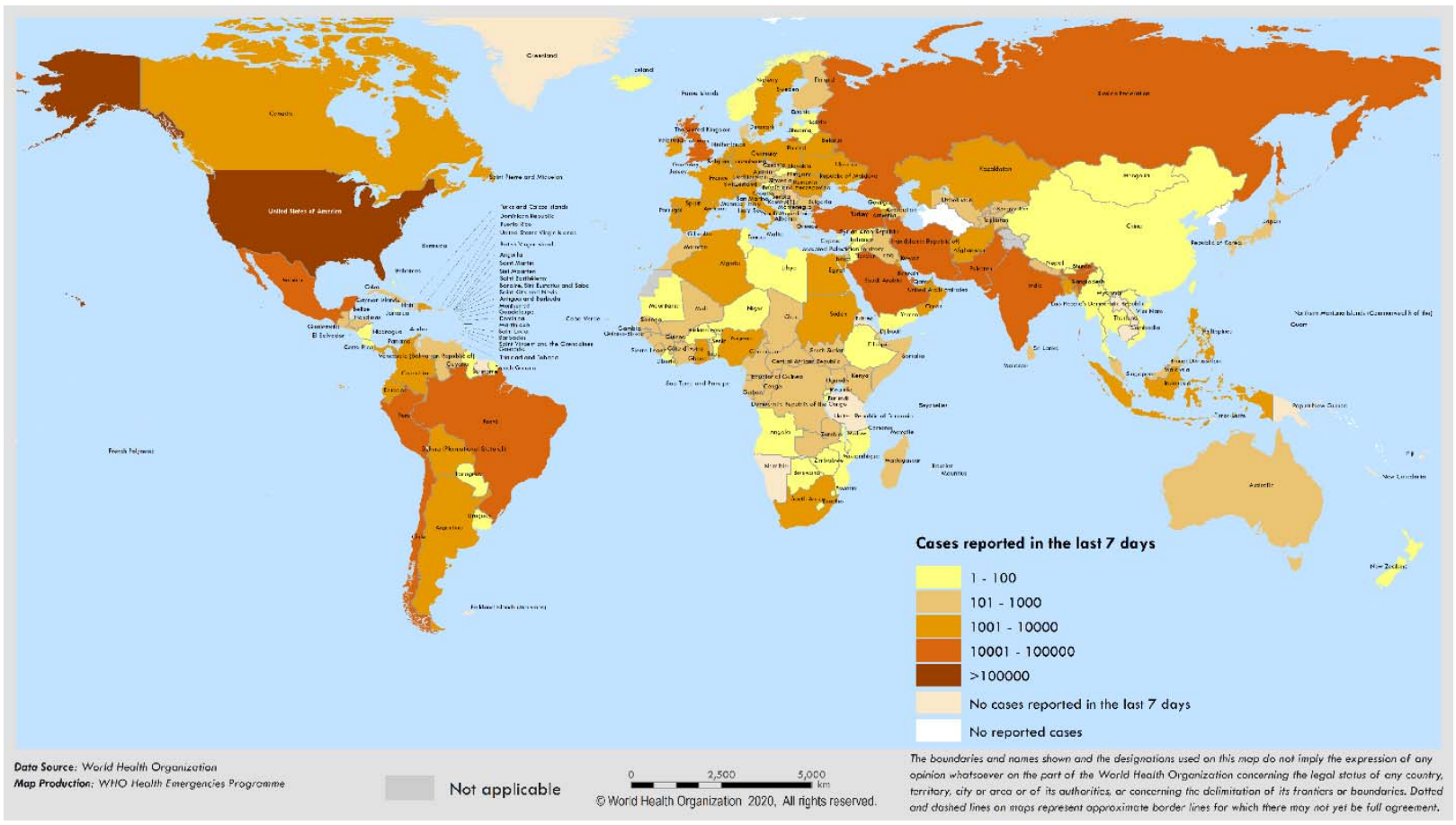

Fig. 1 Global distribution of COVID-19 cases, from WHO Coronavirus Disease (COVID-19) situation reports. ${ }^{[19]}$

The infected patient's mean or median ages were 56, 55.5, and 49.0 as per distinct case studies. ${ }^{[23,24]}$ This similarity in the results was also seen in two reports. The first study was of 1099 patients from 552 hospitals in 31 provinces of China, where the median age came to be 47.0 years and $51.1 \%$ of the infected individuals were between $15-49$ years of age. The second study included 4021 cases in 30 provinces of China where the mean age came to be 49 years and $50.7 \%$ of the infected individuals were between 20-50 years. In both cases, the patients were suffering acute respiratory distress (ARD) and pneumonia. ${ }^{[27,28]}$ The infection of the virus shows no gender specificity. In some countries, infected men are high while in some countries infected women are high. But there is a gender gap seen in the mortality rate. As per various articles, it can be stated that men face a higher risk of death in comparison with women. ${ }^{[29-31]}$ Answer for this may be immune or hormonal factors, but the actual reason is still unclear. ${ }^{[32,33]}$ In comparison with the SARS mortality rate, COVID-19 shows no uniqueness, as a similar case has been seen in the earlier SARS outbreak too. ${ }^{[34]}$

\section{Virology}

The COVID-19 is caused by novel type coronavirus (nCoV-19), which was named as Severe Acute Respiratory Syndrome Coronavirus Two (SARS-CoV-2) later on. Coronaviruses belong to a family within the order of Nidovirales, i.e. viruses that replicate forming a nested set of mRNAs ("Nido-" for "nest"). Alpha Coronaviruses (HCoV229E and HCoV-NL63) and beta Coronaviruses (HCoVHKU1, HCoV-OC43) are the two genera, in which the human Coronaviruses exist and cause Middle East respiratory syndrome coronavirus [MERS-CoV], and the severe acute respiratory syndrome coronavirus [SARS-CoV].

Gripping the genetics of viruses is essential in the production of drugs and vaccines. SARS-CoV-2 virion (Fig. 2) is a spherical containing single-stranded positivesense RNA and 50-200 nanometers in diameter. ${ }^{[35]}$ SARSCoV-2 has four structural proteins, known as the $\mathrm{S}$ (spike), $\mathrm{E}$ (envelope), $\mathrm{M}$ (membrane), and $\mathrm{N}$ (nucleocapsid) proteins. $\mathrm{N}$ protein comprises the RNA genome, and the $\mathrm{S}, \mathrm{E}$, and $\mathrm{M}$ proteins together form the viral envelope. ${ }^{[36]}$ The atomiclevel imaging of the spike protein has been captured using cryogenic electron microscopy ${ }^{[37,38]}$ and revealed that the protein is responsible for the attachment and fusion with the membrane of a host cell. The affinity of the virus with the host is understood by performing protein modeling experiments.

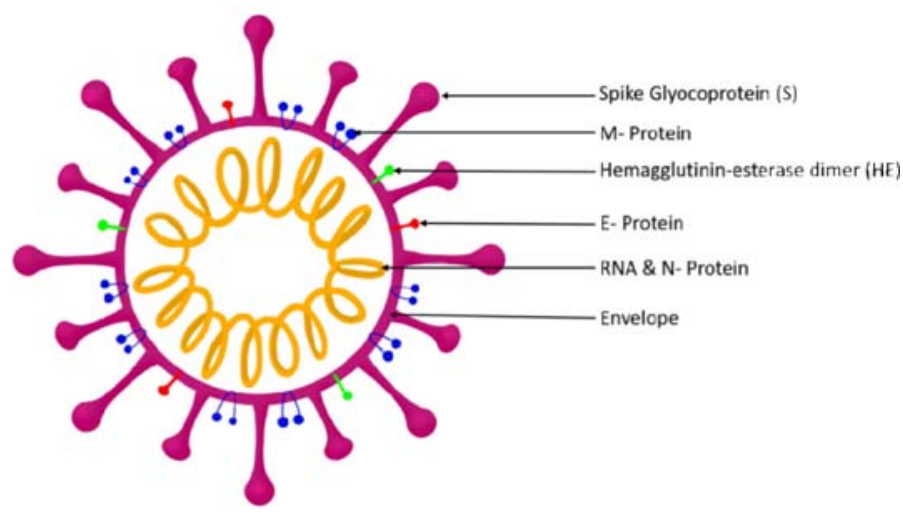

Fig. 2 Cross-sectional view of Coronavirus. Here, SARS-CoV-2 spike homotrimer with one protein subunit is highlighted, ${ }^{[4]}$ and the angiotensin-converting enzyme 2 (ACE2) binding domain (i.e. the $\mathrm{RBD})$ is in magenta. 
It suggests that the Spike protein binds with the receptor angiotensin-converting enzyme 2, i.e., ACE2 is the entry point of the virus in the human body. ${ }^{[39]}$ Groups from China and the United States have shown the action of SARS-CoV-2 on ACE2 receptor by working on methods such as full virus genome and reverse genetic methods. ${ }^{[0-42]}$ Studies show that SARS-CoV-2 has a higher affinity to human ACE2 as compared to the original SARS virus strain. $^{[43]}$

\subsection{Genome, entry, and life cycle of Coronavirus}

The s-s RNA genomes of $\mathrm{CoV}$ encode two large genes (i.e., the ORF1a and ORF1b genes), and encode 16 nonstructural proteins (nsp1-nsp16) that are conserved in all Coronaviruses (Fig. 3). The structural genes encode the structural proteins, i.e., spike (S), envelope (E), membrane $(\mathrm{M})$, and nucleocapsid $(\mathrm{N})$, which are common to all Coronaviruses. Accessory genes (green colored) are unique properties of Coronaviruses in terms of number, genomic organization, sequence, and performance. Beneath genome organization comprises the structure of every $\mathrm{S}$ protein. $\mathrm{S}$ protein has the $\mathrm{S} 1$ and $\mathrm{S} 2$ subunits (named as $\mathrm{S} 1$ and $\mathrm{S} 2$ in Fig. 3). Residue numbers in each region represent their positions within the $\mathrm{S}$ protein of SARS and MERS. The $\mathrm{S} 1 / \mathrm{S} 2$ cleavage sites are highlighted by the yellow line. The terms are: CP- cytoplasm domain; FP- fusion peptide; HRheptad repeat; RBD- receptor-binding domain; RBMreceptor-binding motif; SP- signal peptide; and TM- transmembrane domain. ${ }^{[45]}$

The genome of SARS-CoV-2 is like that of typical CoVs containing at least ten open reading frames (ORFs). The first ORFs (ORF1a/b), about two-thirds of viral RNA, are translated into two large polyproteins. In SARS-CoV and MERS-CoV, two polyproteins, i.e., protein phosphatase $1 \alpha$ (ppla) and pplab, are processed into 16 non-structural proteins (nsp1-nsp16), which form the viral replicase transcriptase complex. The membranes start from the rough endoplasmic reticulum and it rearranges rough endoplasmic reticulam (RER) into double-membrane vesicles where the virus replicates and transcription occurs. The remaining ORFs of SARS-CoV-2, which are on the one-third of the genome, encode 4 main structural proteins ( $\mathrm{S}, \mathrm{E}, \mathrm{N}$ and $\mathrm{M}$ proteins (Fig. 4), and several accessory proteins with unknown functions which rarely take part in the viral replication.

As discussed earlier, the SARS-CoV-2, just like SARS-CoV, requires the ACE2 as a receptor to enter cells (Fig. 5). ${ }^{[47]}$ The binding of the virus to host cell receptors is a significant determinant of the pathogenesis of infection. SARS-CoV most likely originated from bats ${ }^{[48]}$ and adapted to non-bat ACE2 variants as it crossed species to infect humans. ${ }^{[49]}$ Dipeptidyl peptidase 4 (DPP4, also known as CD26) was identified to be a functional receptor for MERS-CoV because the receptor-binding S1 domain of the MERS-CoV spike protein was co-purified with DPP4 specifically from lysates of susceptible Huh-7 cells. ${ }^{[50]}$ MERS-CoV can bind DPP4 for various species, which are
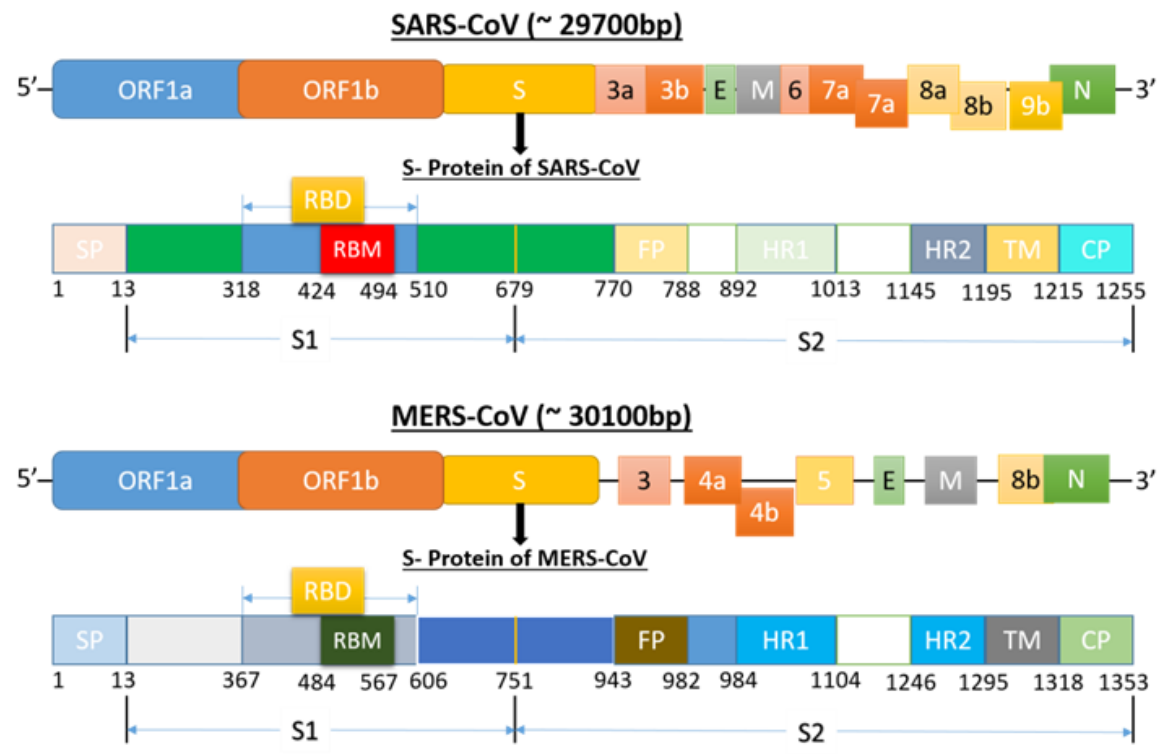

Fig. 3 Genomic configuration of SARS and MERS-CoV, modified from [45].

SARS-CoV-2 ( 299003bp)

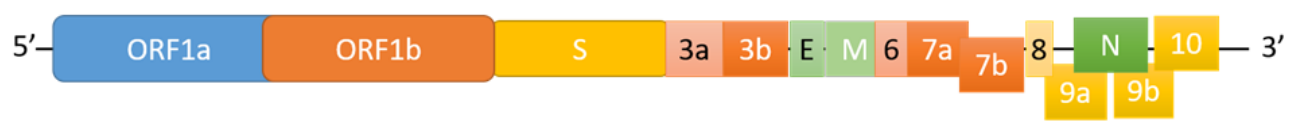

Fig. 4. Genome of SARS-CoV-2. ${ }^{[46]}$ 


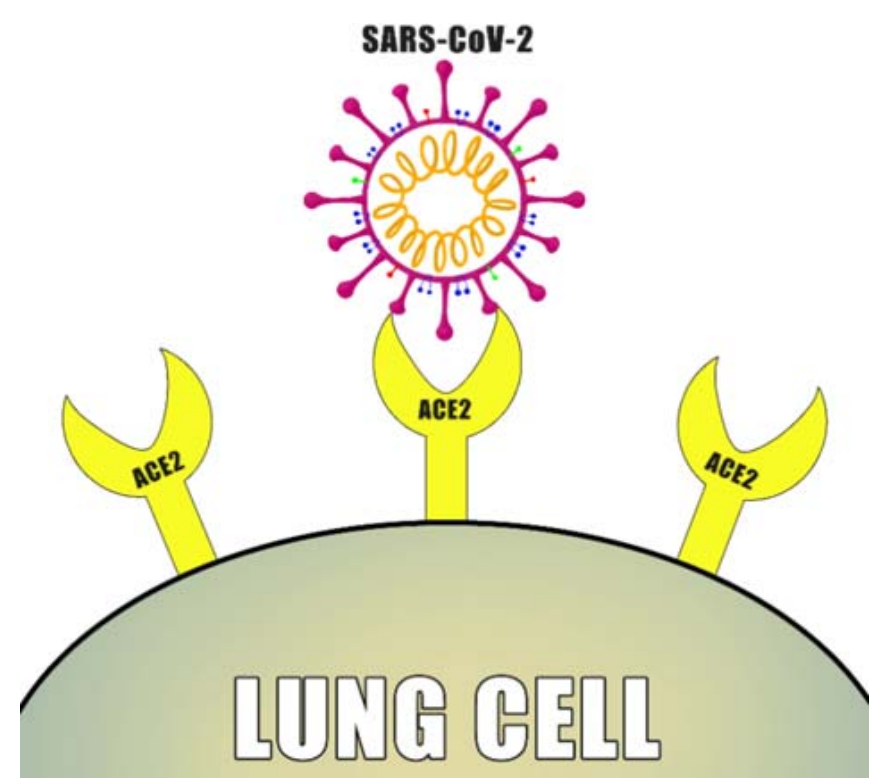

Fig. 5 Entry of SARS-CoV-2 in human, modified from [47].

able to promote the transmission to humans as well as other species, and infection of cells from varied species. ${ }^{[51]}$ Understanding the related effects of receptor binding and the action of protease will help in predicting the specificity of these animals' intervened Coronaviruses which infect humans and their possible adaptations.

\subsection{Genomic variations in SARS-CoV-2}

Coronavirus is mainly responsible for causing mild cold in humans, which has a phenotypic structure similar to that of the new COVID-19, but there is a difference in the genetic composition of the new virus. Here, the variation in the genetic composition of all different Coronaviruses strains is studied. According to research, the variation in the genomic nucleotides of SARS-CoV-2 with a bat-related SARS-CoV (SARSr-CoV; RaTG13) was $4 \%$. Also, there is a $17 \%$ difference in their neutral sites, which suggests that the difference between the two viruses is very large as compared to the estimated. This study also suggests that the new variations at the functional sites of the receptor-binding domain (RBD) of Spike which has been observed in the SARS-CoV-2 may be because of the mutations or natural selection over recombination in the Pangolins SARSr-CoV. They have studied around 103 genomes of SARS-CoV- 2. The genomes have evolved into two major types $\mathrm{L}$ and $\mathrm{S}$. The $\mathrm{L}$ type is around $70 \%$ while the $\mathrm{S}$ type is $30 \%$. The $\mathrm{S}$ type is considered to be the ancestral version. L type is responsible for the early outbreak caused in Wuhan, China. After comparing various strains of viruses, all these results pointed out that the viruses were found in bats and pangolins. These mutations in SARS-CoV-2 are responsible for causing high damages in humans. Here they have focused on the ORFs i.e. only reading frames of all the viral strain. The reference genome of SARS-CoV-2 is NC_045512. We compared this with bat and pangolin related Coronaviruses. Bat related SARS Coronaviruses (such as RaTG13, ZCX21,
ZC45, BM48-31) $)^{[52]}$ has been used for comparison. Six Pangolin SARSr-CoV genomes were from Guangxi (Table S1 of [53]). On comparison of ORFs of the following with the reference, many viruses have ORFs similar to that of SARS-CoV-2 except ORF8 and ORF10 (Table 1 of [52]).

Also, the Phylogenetic tree (Fig. 1A of [52]), which was prepared using the synonymous sites, showed that SARS- CoV-2 was closest to RaTG13 then came the GD Pangolin SARSr-CoV which was followed by ZC45 \& ZXC21 and then by human SARS-CoV and BM48-31(Fig. 1A of [52]). ${ }^{[52]}$ The higher value of dS of spike according to Table 1 of [52] data shows that the reason may be a high mutation rate or by natural selection, which favors the synonymous substitutions as the $\mathrm{dN}$ substitutions are negative. ${ }^{[10]}$ The differences between SARS-CoV-2 and SARS-CoV can be understood by seeing Fig. 1B of [52], which shows that five out of six amino acids residues are different in the RBD. ${ }^{[52]}$ While the 3D structural analysis suggests that SARS-CoV-2 has a more binding affinity to the ACE2 receptor as compared to SARS-CoV. ${ }^{[54]}$ Also, these 6 amino acids are similar between GD-Pangolin-CoV and SARS-CoV-2. ${ }^{[5]}$ In contrary, the genomes of SARS-CoV-2 match maximum with the genomes of RaTG13, but out of six, only one functional site is identical between them (Fig. 1B of [52]).

By considering the synonymous substitution rate, the time for recombination of the gene to form SARS-CoV-2 spike RBD was about 19.8 to 55.4 years ago. ${ }^{[56]}$ We can conclude that the sharing of critical amino acid sites between SARS-CoV-2 and GD-Pangolin-CoV may have taken place because of random mutations with natural selection. ${ }^{[52]}$

\subsection{The assortment of ACE2 receptor in Humans}

The metallopeptidase viz. angiotensin-converting enzyme 2 is considered as the entry point for SARS-CoV-2 in the human body. Studies suggest that the ACE2 mRNA is present in the body overall with its protein expression to be unknown. ${ }^{[57]}$ Since this receptor is the principal reason for the entry of the virus, its distribution in the body is essential to know. It is present on the epithelial cells of lung alveolar and also on the enterocytes of the small intestine. ${ }^{[57]}$ Tests suggest the abundance of ACE2 in the epithelia of the lungs and the small intestine of humans. ${ }^{[57]}$ Evidence of the distribution of ACE2 in the brain makes the brain to be one of the potential targets of SARS-CoV-2 after lungs and intestine. The moment of COVID-19 causing the virus to the brain may take place through the cribriform plate close to the olfactory bulb which may reach and affect the brain. ${ }^{[58]}$ One more feasible route for the virus to enter the brain is through the transcritical route, which is for other CNS targeting pathogens. ${ }^{[59]}$ This distribution is the basis of the pathogenesis of the SARS-CoV-2 intervention in the human body. Understanding the distribution of the target host receptor is very essential in treating the disease. 


\subsection{Incubation period of SARS-CoV-2}

The incubation period of the virus plays a pivotal role in understanding the precautionary steps to be safeguarding ourselves from getting infected. It is not related but still, it stands for the basis of a person showing initial symptoms and time we should quarantine the patient. Various case studies have been analyzed until the date. But to decide correct result will require a number of more case studies. If the proportion of cases is more than we can get accurate results considering the time long enough to show the symptoms. According to $\mathrm{WHO}$, the incubation period was assumed to be $0-14$ days and by the ECDC, it is around 2-12 days. ${ }^{[60]}$ They estimate the mean incubation period to be 6.4 days ranging from 2.1 to 11.1 days. $^{[61]}$

\section{Modes of Dissemination of SARS-CoV-2}

The modes for the dissemination of SARS-CoV-2 can be summarized in Table 4.

Table 4. Modes of dissemination of COVID-19.

\begin{tabular}{|c|c|}
\hline $\begin{array}{c}\text { Mode of Transmission } \\
\text { of SARS-CoV-2 }\end{array}$ & Description \\
\hline $\begin{array}{l}\text { Human to human } \\
\text { transmission, via } \\
\text { touch }^{[62]}\end{array}$ & $\begin{array}{l}\text { This transmission occurs by touching an infected individual infected surface (skin-to- skin or infected non-living } \\
\text { object) which mediates through mouth, nose \& eyes. This can transmit via inhaling the respiratory droplets, which } \\
\text { contain a virus. These viruses survive for a longer time on surfaces such as Al, sterile sponges, or latex gloves } \\
\text { which increase the chance of transmission via touch. }{ }^{[62]}\end{array}$ \\
\hline $\begin{array}{l}\text { Transmission via } \\
\text { inhalation of aerosol } \\
\text { droplets }^{[62]}\end{array}$ & $\begin{array}{l}\text { Small droplets which are exhaled by an infected individual may be aerosol droplets that remain in the air for a } \\
\text { prolonged time, which assist the long-range transmission through movement in the air. }{ }^{[62]}\end{array}$ \\
\hline $\begin{array}{l}\text { Transmission through } \\
\text { feces }^{[62]}\end{array}$ & $\begin{array}{l}\text { SARS-CoV-2 has been seen positive in stool samples of an infected person and this virus can survive in stools up } \\
\text { to } 4 \text { days. }{ }^{\left[{ }^{62]}\right.} \text { Also, coronavirus remains infectious in sewage and water for days to weeks. }{ }^{[63]}\end{array}$ \\
\hline $\begin{array}{l}\text { Transmission via } \\
\text { airborne dust }\end{array}$ & $\begin{array}{l}\text { Microorganisms in airborne particulate matter or dust have a link with infectious diseases. }{ }^{[64]} \text { As pollution is a } \\
\text { major issue in developing nations, still the transmission of SARS-CoV-2 via airborne dust is under investigation. } \\
\text { The virus may lead to transmission of the virus at longer distances if adsorbed on the particulate matter. To } \\
\text { understand the transmission related to airborne, dusts need be continuous monitored for the virus. }{ }^{[62]}\end{array}$ \\
\hline
\end{tabular}

\section{Diagnosis of Infected personnel}

The diagnosis of infected personnel can be summarized in Table 5 .

Table 5. Diagnosis technique of COVID-19.

Technique

Nucleic acid test

Serologic diagnosis

CRISPR/Cas13 system

Imaging technology

Sputum test
Description

This is done by detecting the viral sequence by using RT-PCR, the Biotech company has developed nucleic acid detection kits. ${ }^{[65]}$ The nucleic acid test came to be negative for a un-infected person. To resolve this, they had invented better rapid viral nucleic tests. Nucleic acid test paper is developed for the swift identification of SARS-CoV-2. ${ }^{[66]}$

Patients infected with SARS-CoV-2 show acute serological responses. Combined with immuno- chromatography or colloidal gold technology, detection reagents for the same have been developed. ${ }^{\text {[67-69] }}$

CRISPR/Cas13 based SHERLOCK (specific high sensitivity enzymatic reporter unlocking) technology has been developed to detect SARS-CoV-2. Still, this system is supposed to be verified as it has not been clinically tested on COVID-19 patients. $^{[70]}$

CT or chest scanning is one of the essential tools in diagnosing COVID-19. Similar feature of CT images of maximum COVID-19 patients shows a bilateral distribution of patchy and ground-glass opacity. ${ }^{[71]}$

We consider this test to be the most efficient one. The throat swab tests comes negative after quarantining the patient and treating them with anti-viral but the sputum test comes to be positive which suggests its accuracy. ${ }^{[72]}$

\section{Treatment}

The major concern is treating COVID-19, which is still a developing process. For the same, there are some approaches made by scientists throughout. Still, there is no such specific drug or vaccine available for treating COVID19. Various potential inhibitors are being used. For a better treatment understanding, various stages of the infections are essential. Various tests are to be carried such as Hemogram (HB/CBC/ESR), Baseline hemogram, Blood sugar random,
Liver Function Test (LFT), Renal Function Tests (RFT), X-ray chest, electrocardiogram (ECG), and 2D echocardiography for deciding the treatment procedures. Here, we have listed various potential inhibitors which can be used or are in use today, various vaccines related programs by various institutes as well as the most advanced Plasma Therapy.

As there is no specified drug for COVID-19 yet, health professionals use fluids to reduce the risk of dehydration, 
also medications are given to reduce fever, supplementary oxygen is given in severe cases where respirators or ventilators are being used. There are some countries where the drug hydroxychloroquine is used while in some countries, ivermectin is used in combination with doxycycline, which has given astounding results in the treatment of COVID-19 $9^{[92]}$ and may be considered for further in-vitro studies for treating COVID-19.

\subsection{Clinically used drugs}

The reported possible inhibitors of COVID-19 can be summarized in Table 6.

Table 6. Possible inhibitors of COVID-19.

\begin{tabular}{|c|c|c|c|}
\hline Drug & & Structure & Description \\
\hline Ribavirin & [73] & & $\begin{array}{l}\text { It is an antiviral drug used to treat hepatitis C. It is used as a } \\
\text { combination with interferon } \alpha \text { (IFN). As approved by FDA, its } \\
\text { active site is RdRp. Score Ribavirin was } 109.5 \mu \mathrm{M} \text { half of the } \\
\text { maximal concentration against SARS-CoV-2. } .^{[74]}\end{array}$ \\
\hline Sofosbuvir & {$[75]$} & & $\begin{array}{l}\text { This drug behaves as a nucleotide polymerase inhibitor for treating } \\
\text { hepatitis C. They use this drug in amalgamation with interferon or } \\
\text { Ribavirin. This was used in the treatment of the Zika virus. }{ }^{[7]}\end{array}$ \\
\hline Lopinavir/Ritonavir & [77] & & $\begin{array}{l}\text { The drug is used in the protease prohibition and targets HIV. It } \\
\text { stops the formation of the viral protein, and disrupts the proteolytic } \\
\text { process by mimicking the structure of the protein as cleaved by the } \\
\text { HIV protease. It has shown the recovery in COVID-19 pneumonia } \\
\text { patients when used in combination with drug oseltamivir. }{ }^{[78]}\end{array}$ \\
\hline Remdesivir & [79] & & $\begin{array}{l}\text { It is an adenosine nucleotide analog, used against Ebola, } \\
\text { SARS-CoV, and MERS-CoV. It's a drug with the potential of } \\
\text { premature termination of the virus by invading the incipient viral } \\
\text { RNA. }{ }^{[0]} \text { A study showed that Remdesivir scored } 0.77 \mu \mathrm{M} \text { at } \\
\text { half-maximal concentration against COVID-19 and showed the } \\
\text { blocking of viral infection. But according to the latest news, the } \\
\text { clinical trial failed on critical patients of COVID-19. }{ }^{[81]}\end{array}$ \\
\hline
\end{tabular}


Continued

\begin{tabular}{|c|c|c|}
\hline Drug & Structure & Description \\
\hline Chloroquine & [82] & $\begin{array}{l}\text { It's an anti-malarial drug showing potential to treat avian influenza } \\
\text { A }^{[83]} \text { This drug has antiviral properties and shows } 1.13 \mu \mathrm{M} \text { at a } \\
\text { half-maximal concentration in inhibiting SARS-CoV-2. The } \\
\text { augmentation of the endosomal pH required for viral fusion has } \\
\text { blocked the viral infection. }{ }^{[84,85]}\end{array}$ \\
\hline Hydroxy-chloroquine & [86] & $\begin{array}{l}\text { Hydroxychloroquine is an analog of chloroquine but with lesser } \\
\text { side effects. It has shown successful in-vitro activity against } \\
\text { SARS-CoV in a previous outbreak. }{ }^{[87]} \text { The in-vitro anti-SARS- } \\
\text { CoV-2 activity of both the drugs was compared and hydroxychloroquine } \\
\text { came to be superior to chloroquine. }{ }^{[88]} \text { The federal agency of the } \\
\text { United States Department of Health and Human Services issued an } \\
\text { emergency use authorization for chloroquine/ hydroxychloroquine } \\
\text { to treat COVID-19 on March } 28,2020 .{ }^{[89]}\end{array}$ \\
\hline Ivermectin & [90] & $\begin{array}{l}\text { Ivermectin is an antiprotozoal drug. }{ }^{[91]} \text { This drug helps in curing } \\
\text { the parasitic infections to human. }{ }^{[91]} \text { From a recent study, it has } \\
\text { been seen that ivermectin in combination with doxycycline, which } \\
\text { is an antibiotic, has shown astounding results in the treatment of } \\
\text { COVID-19. }{ }^{[92]} \text { Where the Doctors have claimed that around } 60 \\
\text { patients recovered with this combination within } 4 \text { days only. }{ }^{[92]}\end{array}$ \\
\hline
\end{tabular}

\subsection{Potential Vaccines}

The purpose of vaccination is to build up the immunity of the individual to fight against the foreign virus, which has infected our body systems. COVID-19 is a threat that requires a vaccine as soon as possible. Various research is going on the vaccines can be classified as follows:

a. Whole virus vaccines -These are half-killed or inactive whole virus vaccines, which have been the oldest strategy used for viral vaccination. These vaccines have an advantage and a disadvantage. They have intrinsic immunogenicity and they can stimulate toll-like receptors, however, these kinds of vaccines require whole slew safety tests to ensure lives. ${ }^{\text {[93] }}$

b. Sub-unit vaccines-Preventing the spike protein to bind with the host ACE2 receptor forms the basis of this vaccine to generate antibodies against it. ${ }^{[94]}$

c. Nucleic acid vaccines-This immunization is done with DNA. This technique is not familiar with humans, but various unknown technologies have made this possible to use on humans too.

The major COVID-19 vaccine development project, which has been taken place by various institutions throughout the globe such as the Codagenix/Serum Institute of India, is working on the live-attenuated vaccine. ${ }^{[94]}$ For example, the Janssen i.e. Johnson and Johnson are working on Adenovirusvectored Vaccine using AdVac $\AA$ and PER.C6 $®$ technology, ${ }^{[95]}$ which are whole virus vaccines. Some institutes are working on subunit vaccines like the Vaxart, which is working on oral recombinant protein vaccine using VAAST platform, ${ }^{[96]}$ the Novavax on recombinant nanoparticle technology, ${ }^{[97]}$ the University of Queensland/CEPI is working on protein-based vaccine using molecular clamp platform, ${ }^{[98]}$ the Clover Biopharmaceuticals is working on S-trimer recombinant protein using Trimer-Tag technology, ${ }^{[99]}$ the Baylor College of Medicine, Fudan University, New York Blood Center, Unit Texas Medical Branch working on Coronavirus RBD protein-based vaccine. ${ }^{[100]}$ Also, some institutes are working on Nucleic acid vaccines such as Moderna/NIH/CEPI $\&$ CureVac/CEPI are working on mRNA vaccine ${ }^{[101,102]}$ and Inovio/Beijing Advaccine Biotechnology Co. /CEPI are working on DNA vaccine (INO-4800, based on INO-4700 MERS vaccine). ${ }^{[103]}$

\subsection{Treatment using plasma therapy}

In this devastating situation, with no specified drug for 
COVID-19 treatment, plasma therapy emerged as a new strategy in the treatment. Scientists utilized the single-cell analysis technique to identify different antibodies from COVID-19 patients that may neutralize the novel coronavirus. This is the most advanced therapeutics against the deadly COVID-19. From 8558 antigen-binding $\operatorname{IgG1}^{+}$clonotypes, around 14 neutralizing antibodies, that have potential, were identified, out of which the one with the highest potent is BD-368-2, against an authentic SARS-CoV-2. These human neutralizing antibodies can be discovered using highthroughput single B-cell sequencing in the response to pandemic causing SARS-CoV-2. ${ }^{[104]}$

\section{Precautionary measures}

The general precautionary measures, which should be followed, are: $:^{[105-108]}$

- Washing hands frequently with soap or with alcoholbased ( $70 \%$ alcohol) solutions.

- Always using mask when going outdoors, especially when suffering from cold or cough.

- Staying inside the houses.

- Maintaining social distancing.

- Sanitizing all inanimate objects in houses from time to time.

- If symptoms of cold or cough or fever persist, then consult a doctor for the check-up.

- Using gloves when going outside.

- Washing vegetables and fruits before use.

- Drinking hot water from time to time.

\section{Conclusion and future tasks}

There is no FDA-approved drug available to cure COVID19 till date, so all precautionary measures are important to be followed for health care workers. They have to follow all the measures while treating a suspected COVID-19 patient. Disinfecting hands with an alcohol-based hand rub $(70 \%$ alcohol is effective) or washing with soap and water for 30 seconds is effective in controlling the transmission of the virus. Maintaining social distancing even after the lockdown period will be as important as avoiding touching eyes, nose, and mouth. This can be aided by wearing masks and practice respiratory hygiene. Any person with symptoms of fever, cough, and difficulty in breathing, needs to be checked for the virus in a diagnostic center and seeks medical care as early as possible. If the case is positive, the patient should be isolated rather quarantined and when recovered donate the blood for plasma therapy. The medical staff needs to be provided with a proper Personnel Protective Equipment kit (PPE kit) and all the hospitals should have the diagnostic facility. CADDD (Computer-Aided Drug Discovery and Development) can be used to accelerate the development of drugs and vaccines.

\section{Supporting information}

Not applicable

\section{Conflict of Interest}

There is no conflict of interest.

\section{References}

[1] S. Su, G. Wong and W. Shi, Trends Microbiol., 2016, 24, 490-502. doi: 10.1016/j.tim.2016.03.003.

[2] S. Perlman and J. Netland, Nat. Rev. Microbiol., 2009, 7, 439-450. doi: 10.1038/nrmicro2147.

[3] Decontamination and reprocessing of medical devices for health-care facilities, Geneva, World Health Organization; 2016, https://www.who.int/infectionprevention/publications/decontami nation/en/, accessed 20 January 2020.

[4] N. Zhong, B. Zheng, Y. Li, L. Poon, Z. Xie and K. Chan, Lancet, 2003, 362, 1353-1358. doi: 10.1016/s0140-6736(03)14630-2.

[5] E. de Wit, N. van Doremalen, D. Falzarano and V. J. Munster, Nat. Rev. Microbiol., 2016, 14, 523-534. doi: 10.1038/nrmicro. 2016.81 .

[6] N. Wang, X. Shi, L. Jiang, S. Zhang, D. Wang and P. Tong, Cell Res., 2013, 23, 986-993. doi: 10.1038/cr.2013.92.

[7] J. Cui, F. Li and Z. L. Shi, Nat. Rev. Microbiol., 2019, 17(3), 181-192. doi: 10.1038/s41579-018-0118-9.

[8] C. C. Lai, T. P. Shih, W. C. Ko, H. J. Tang and P. R. Hsueh, Int. J. Antimicrob. Ag., 2020, 55, 105924. doi: 10.1016/j.jjantimicag. 2020.105924.

[9] World Health Organization. (2020). Laboratory testing for corona virus disease 2019(DVOVI-19) insuspected human cases: interim guidance, 2 March 2020. World Health Organization. https://apps.who.int/iris/handle/10665/331329

[10] G. Hanson and J. Coller. Nat. Rev. Mol. Cell bio. 2018, 19, 20-30. doi: 10.1038/nrm.2017.91.

[11] Y. Jin, L. Cai and Z. Cheng, Mil. Med. Res., 2020, 7, 4. doi: 10.1186/s40779-020-0233-6.

[12] R. Lu, X. Zhao and J. Li, Lancet, 2020, 395, 565-574. doi: 10.1016/S0140-6736(20)30251-8.

[13] T. T. Lam, M. H. Shum and H. Zhu, Nature, 2020, doi: 10.1038/s41586-020-2169-0.

[14] X. Y. Ge, J. L. Li, X. L. Yang, A. A. Chmura, G. Zhu, J. H. Epstein, J. K. Mazet, B. Hu, W. Zhang and C. Peng, Nature, 2013, 503, 535-538. doi: 10.1038/nature12711.

[15] S. K. P. Lau, P. C. Y. Woo, K. S. M. Li, Y. Huang, H. W. Tsoi, B. H. L. Wong, S. S. Y. Wong, S. Y. Leung, K. H. Chan and K. Y. Yuen, Proc. Natl. Acad. Sci., 2005, 102, 14040-14045. doi: 10.1073/pnas.0506735102.

[16] Q. Li, X. Guan, P. Wu, X. Wang, L. Zhou and Y. Tong, New Engl. J. Med., 2020, 382(13), 1199-1207. doi: 10.1056/NEJMoa 2001316.

[17] J. F. Chan, S. Yuan and K. H. Kok, Lancet, 2020, 395, 514-523. doi: 10.1016/S0140-6736(20)30154-9.

[18] M. Lipsitch, T. Cohen, B. Cooper, J. M. Robins, S. Ma and L. James, Science, 2003, 300, 1966-1970. doi: 10.1126/science. 1086616.

[19] WHO situation report, https://www.who.int/docs/default-source/ coronaviruse/situation-reports/20200518-covid-19-sitrep-119.pdf ?sfvrsn=4bd9de25 4, Accessed on $18^{\text {th }}$, May 2020. 
[20] Worldometer for accessing population, https://www.worldometers. info/

[21] Observers Research Foundation, https://www.orfonline.org/expertspeak/how-china-overcame-the-covid-19-pandemic-64442/, Accessed on $19^{\text {th }}$ May 2020.

[22] K. Liu, Y. Y. Fang, Y. Deng, W. Liu, M. F. Wang, J. P. Ma, W. Xiao, Y. N. Wang, M. H. Zhong, C. H. Li, G. C. Li and H. Guo, Chinese Medical Journal, 2020, 133, 1025-1031. doi: 10.1097/ CM9.0000000000000744.

[23] N. Chen, M. Zhou, X. Dong, J. Qu, F. Gong and Y. Han, Lancet, 2020, 395, 507-513. doi: 10.1016/S0140-6736(20)30211-7.

[24] D. Wang, B. Hu, C. Hu, F. Zhu, X. Liu and J. Zhang, JAMA., 2020, 323, 1061-1069. doi: 10.1001/jama.2020.1585.

[25] E. M. Rodriguez, B. B. Maoz and K. Dorshkind, J. Clin. Invest., 2013, 123, 958-965. doi: 10.1172/JCI64096.

[26] The Hindustan Times, https://www.hindustantimes.com/cities/ does-coronavirus-affect-children-differently/story-uDL9ru1GFQ FsvWSznYOROM.html, Accessed on $21^{\text {st }}$ May 2020.

[27] W. J. Guan, Z. Y. Ni, Y. Hu, W. H. Laing, C. Q. Ou and J. X. He, Med Rxiv, 2020, Feb 9. doi: 10.1101/2020.02.06.20020974.

[28] Y. L. Q. Yang, M. J. Liu, Y. X. Wang, A. R. Zhang and N. Jalali, Med Rxiv, 2020, Feb 11. doi: 10.1101/2020.02.10.20021675.

[29] The Washington Post, https://www.washingtonpost.com/health/ 2020/04/04/coronavirus-men/ Accessed on 19th May 2020

[30] Sky News, https://news.sky.com/story/coronavirus-male-securityguards-chefs-and-taxi-drivers-among-those-most-likely-to-diewith-covid-19-says-ons-11986382, Accessed on 19th May 2020.

[31] CNN Health, https://edition.cnn.com/2020/03/24/health/coronavirusgender-mortality-intl/index.html, Accessed on 19th May 2020.

[32] The Guardian, https://www.theguardian.com/world/2020/mar/26/ men-are-much-more-likely-to-die-from-coronavirus-but-why, Accessed on 19th May 2020.

[33] Brookings, https://www.brookings.edu/blog/up-front/2020/05/15/ covid-19-much-more-fatal-for-men-especially-taking-age-into-ac count/, Accessed on 19th May 2020.

[34] J. Karlberg, D. S. Y. Chong and W. Y. Y. Lai, Am. J. Epidemiol., 2004, 159, 229-231. doi: 10.1093/aje/kwh056.

[35] C. Wu, Y. Liu, Y. Yang, P. Zhang, W. Zhong and Y. Wang, Acta Pharm. Sin. B, 2020, 10, 766-788. doi: 10.1016/j.apsb.2020.02. 008.

[36] D. Wrapp, N. Wang, K. S. Corbett, J. A. Goldsmith, C. L. Hsieh and O. Abiona, Science, 2020, 367, 1260-1263. doi: 10. 1126/science.aax0902.

[37] R. F. Mandelbaum, 19 February 2020, https:/gizmodo.com/ scientists-create-atomic-level-image-of-the-new-coronav-184179 5715, Retrieved $2^{\text {nd }}$ May 2020.

[38] X. Xu, P. Chen, J. Wang, J. Feng, H. Zhou and X. Li, Sci. China Life Sci., 2020, 63, 457-460. doi: 10.1007/s11427-020-1637-5.

[39] M. Letko and V. Munster, Bio Rxiv 2020. doi: 10.1101/2020.01. 22.915660 .

[40] M. Letko, A. Marzi and V. Munster, Nat. Microbiol., 2020, 5, 562-569. doi: 10.1038/s41564-020-0688-y.

[41] R. Lu, Lancet, 2020, 395, 565-574. doi: 10.1016/S0140-6736 (20)30251-8

[42] D. Wrapp, N. Wang, K. S. Corbett, J. A. Goldsmith, C. L. Hsieh,
O. Abiona, B. S. Graham and J. S. McLellan, Science, 2020, 367, 1260-1263. doi: 10.1126/science.abb2507.

[43] J. F. W. Chan, S. K. P. Lau, K. K. W. To, V. C. C. Cheng, P. C. Y. Woo and K. Y. Yuen, Clin. Microbiol. Rev., 2015, 28, 465-522. doi: 10.1128/CMR.00102-14.

[44] Severe acute respiratory syndrome coronavirus 2, https://en. wikipedia.org/wiki/Severe_acute_respiratory_syndrome_coronav irus_2, Accessed 7 May 2020.

[45] Z. Song, Y. Xu, L. Bao, L. Zhang, P. Yu, Y. Qu, H. Zhu, W. Zhao, Y. Han and C. Qin, Viruses, 2019, 11, 59. doi: 10.3390/ v11010059.

[46] B. Kan, M. Wang, H. Jing, H. Xu, X. Jiang and M. Yan, J. Virol., 2005, 79, 11892-11900. doi: 10.1128/JVI.79.18.11892-11900. 2005.

[47] B. J. Zheng, Y. Guan, K. H. Wong, J. Zhou, K. L. Wong and B. W. Y. Young, Emerg. Infect. Dis., 2004, 10, 176-178. doi: 10.3201/eid1002.030533.

[48] Z. Shi and Z. Hu, Virus Res., 2008, 133, 74-87. doi: 10.1016/ j.virusres.2007.03.012.

[49] C. Paden, M. Yusof, Z. A. Hammadi, K. Queen, Y. Tao and Y. Eltahir, Zoonoses Public Hlth., 2018, 65, 322-333. doi: 10. 1111/zph.12435.

[50] A. Annan, H. J. Baldwin, V. M. Corman, S. M. Klose, M. Owusu and E. E. Nkrumah, Emerg. Infect. Dis., 2013, 19, 456-459. doi: 10.3201/eid1903.121503.

[51] N. Chen, M. Zhou, X. Dong, J. Qu, F. Gong and Y. Han, Lancet, 2020, 395, 507-513. doi: 10.1016/S0140-6736(20)30211-7.

[52] K. Xiao, J. Zhai, Y. Feng, N. Zhou, X. Zhang and J. J. Zou, Bio Rxiv, 2020, doi: 10.1101/2020.02.17.951335.

[53] T. T. Y. Lam, M. H. H. Shum, H. C. Zhu, Y. G. Tong, X. B. Ni and Y. S. Liao, Bio Rxiv, 2020, doi: 10.1101/2020.02.13.945485.

[54] D. Wrapp, N. Wang, K. S. Corbett, J. A. Goldsmith, C. L. Hsieh and O. Abiona, Bio Rxiv, doi: 10.1101/2020.02.11.944462.

[55] M. C. Wong, S. J. J. Cregeen, N. J. Ajami and J. F. Petrosino, Bio Rxiv, 2020, doi: 10.1101/2020.02.07.939207.

[56] Z. Zhao, H. Li, X. Wu, Y. Zhong, K. Zhang and Y. P. Zhang, BMC Evol. Biol., 2004, 4, 21. doi: 10.1186/1471-2148-4-21.

[57] I. Hamming, W. Timens, M. L. C. Bulthuis, A. T. Lely, G. J. Navis and H. V. Goor, J. Pathol., 2004, 203, 631-637. doi: 10.1002/path. 1570 .

[58] A. M. Baig, A. Khaleeq, U. Ali and H. Syeda, ACS Chem. Neurosci., 2020, 11, 995-998. doi: 10.1021/acschemneuro. $0 \mathrm{c} 00122$.

[59] A. M. Baig, ACS Chem. Neurosci., 2016, 7, 1026-1029. doi: 10.1021/acschemneuro.6b00197.

[60] European Centre for Disease Prevention and Control (ECDC). Q \& A on novel coronavirus. Stockholm: ECDC; 2020. [Accessed 4 Feb 2020]. Available from: https://www.ecdc.europa.eu/en/novelcoronavirus-china/questions-answers

[61] J. A. Backer, D. Klinkenberg and J. Wallinga, MedRxiv, 2020, doi: 10.2807/1560-7917.ES.2020.25.5.2000062.

[62] E. D. Wit, N. V. Doremalen and D. Falzarano, Nat. Rev. Microbiol., 2016, 14, 523-534. doi: 10.1038/nrmicro.2016.81.

[63] S. Perlman and J. Netland, Nat. Rev. Microbiol., 2009, 7, 439-450. doi: 10.1038/ nrmicro2147.

[64] X. Y. Ge, J. L. Li and X. L. Yang, Nature, 2013, 503, 535-538. 
doi: 10.1038/nature12711.

[65] Y. Jin, L. Cai and Z. Cheng, Mil. Med. Res., 2020, 7, 4. doi: 10.1186/s40779-020-0233-6.

[66] C. Huang, Y. Wang and X. Li, Lancet, 2020, 395, 497-506. doi: 10.1016/S0140-6736(20)30183-5.

[67] J. V. Fahy, Clin. Exp. Allergy, 1998, 28, 1047-1049. doi: 10. 1046/j.1365-2222.1998.00330.x.

[68] World Health Organization. Infection prevention and control of epidemic- and pandemic-prone acute respiratory diseases in health care. (Accessed 9 May 2020), https://apps.who.int/iris/ bitstream/handle/10665/112656/9789241507134_eng.pdf?seque nce $=1$

[69] S. Wang, B. Kang, J. Ma, X. Zeng, M. Xiao, J. Guo, M. Cai, J. Yang, Y. Li and X. Meng, MedRxiv, 2020, doi: 10.1101/2020. 02.14.20023028.

[70] Y. Jin, H. Yang, W. Ji, W. Wu, S. Chen, W. Zhang and G. Duan, Viruses, 2020, 12, 372. doi: 10.3390/v12040372.

[71] Decontamination and Reprocessing of Medical Devices for Health-care Facilities, Geneva, World Health Organization, 2016, https://www.who.int/infectionprevention/publications/decontami nation/en/, accessed 8 May 2020.

[72] H. Han, Q. Luo, F. Mo, L. Long and W. Zheng, Lancet Infect Dis., 2020, 20, e79, doi: 10.1016/S1473-3099(20)30224-3.

[73] Own work, Public Domain, https://commons.wikimedia.org/w/ index.php? curid $=1557809$.

[74] A. A. Elfiky, Life Sci., 2020, 248, 117477. doi: 10.1016/j.lfs. 2020.117477.

[75] By Yikrazuul (talk)-Own work, Public Domain, https://commons. wikimedia.org/w/index.php?curid=30536792.

[76] S. U. R. Cheema, M. S. Rehman, G. Hussain, S. S. Cheema and N. Gilani, BMC Nephrol., 2019, 20, 438. doi: 10.1186/s12882019-1631-4.

[77] By vaccinations-own work, https://commons.wikimedia.org/w/index. php? curid=40679645.

[78] C. Wu, Y. Liu, Y. Yang, P. Zhang, W. Zhong, Y. Wang, Q. Wang, Y. Xu, M. Li and X. Li, Acta. Pharm. Sin. B, 2020, 10, 766-788. doi: 10.1016/j.apsb.2020.02.008.

[79] By Lu, Le-Own work, CC BY-SA 4.0, https://commons. wikimedia.org/w/index.php?curid=87311572.

[80] T. K. Warren, R. Jordan, M. K. Lo, A. S. Ray, R. L. Mackman and V. Soloveva, Nature, 2016, 531, 381-385. doi: 10.1038/ nature 17180.

[81] Data on Gilead's remdesivir released by accident show no benefit for coronavirus patients, /https:/www.statnews.com/2020/ 04/23/data-on-gileads-remdesivir-released-by-accident-show-nobenefit-for-coronavirus-patients/.

[82] By Fvasconcellos - self-made by Fvasconcellos, Public Domain, https://commons.wikimedia.org/w/index.php?curid=951881.

[83] Y. Yan, Z. Zou, Y. Sun, X. Li, K. F. Xu, Y. Wei, N. Jin and C. Jiang, Cell Res., 2013, 23(2), 300-302. doi: 10.1038/cr.2012.165.

[84] M. Wang, R. Cao, L. Zhang, X. Yang, J. Liu, M. Xu, Z. Shi, Z. Hu, W. Zhong and G. Xiao, Cell Res., 2020, 30, 269-271. doi: 10.1038/s41422-020-0282-0.

[85] M. J. Vincent, E. Bergeron and S. Benjannet, Virol. J., 2005, 2, 69. doi: 10.1186/1743-422X-2-69.
[86] By Fvasconcellos - self-made by Fvasconcellos, Public Domain, https://commons.wikimedia.org/w/index.php?curid=951878.

[87] C. Biot, W. Daher, N. Chavain, T. Fandeur, J. Khalife, D. Dive and E. De Clercq, J. Med. Chem., 2006, 49, 2845-2849. doi: $10.1021 / \mathrm{jm} 0601856$.

[88] X. Yao, F. Ye, M. Zhang, C. Cui, B. Huang, P. Niu, X. Liu, L. Zhao, E. Dong, C. Song, S. Zhan, R. Lu, H. Li, W. Tan and D. Liu, Clin. Infect. Dis., 2020, doi: 10.1093/cid/ciaa237.

[89] Lenzer J. Covid-19: the US gives emergency approval to hydroxychloroquine despite lack of evidence. BMJ. 2020; 369:m1335.

[90] By Fvasconcellos 22:23, 10 October 2007 (UTC)-Own work, Public Domain, https://commons.wikimedia.org/w/index.php?curid= 2896448, Accessed on $23^{\text {rd }}$ May 2020.

[91] Web MD, https://www.webmd.com/drugs/2/drug-1122/ivermectinoral/details, Accessed on $23^{\text {rd }}$ May 2020.

[92] Express Pharma, https://www.expresspharma.in/covid19-updates/ bangladeshi-doctors-claim-to-have-found-drug-combination-to-c ure-covid-19-patients/, Accessed on $23^{\text {rd }}$ May 2020.

[93] Pong W. A dozen vaccine programs underway as WHO declares coronavirus public health emergency. Biocentury. 2020. https:// www.biocentury.com/article/304328/industry-and-academiccent ers-are-rushing-to-create-new-vaccines-and-therapeuticstargeting -coronavirus. Accessed 28 Feb 2020.

[94] BioSpace, Codagenix and Serum Institute of India Initiate Co, Development of a Scalable, Live-Attenuated Vaccine Against the 2019 Novel Coronavirus, COVID-19. 2020. https://www. biospace.com/article/releases/codagenix-and-serum-institute-of-i ndiainitiate-co-development-of-a-scalable-live-attenuated-vaccin eagainst-the-2019-novel-coronavirus-covid-19/. Accessed 2/13/ 2020.

[95] S. Jiang, M. E. Bottazzi, L. Du, S. Lustigman, C. T. Tseng and E. Curti, Expert Rev. Vaccines, 2012, 11, 1405-1413. doi: 10. 1586/erv.12.126.

[96] Novel Coronavirus, jnjnews, 2020, https://www.jnj.com/ coronavirus. Accessed February 10, 2020.

[97] Vaxart, PipelineReview.com, Vaxart Announces Initiation of Coronavirus Vaccine Program. 2020, https://pipelinereview.com/ index.php/2020020273689/Vaccines/Vaxart-Announces-Initi ation of-Coronavirus-Vaccine-Program.html, Accessed 28 Feb 2020 .

[98] Pharmaceutical Technology N, Coronavirus, Vir Biotechnology, and Novavax announce vaccine plans, 2020, https://www. pharmaceutical-technology.com/news/coronavirus-virbiotechnol ogy-novavax-vaccine/, Accessed 28 Feb 2020.

[99] Hennessy J. Australia's been asked to make a coronavirus vaccine at 'unprecedented speed', Science Alert, 2020, https:// www.sciencealert.com/australian-scientists-asked-to-make-coron avirusvaccine-at-unprecedented-speed, Accessed 28 Feb 2020.

[100]Clover Biopharmaceuticals, Clover initiates the development of a recombinant subunit-trimer vaccine for Wuhan coronavirus (2019-nCoV), 2020.

[101]Mukherjee S, The first coronavirus drug candidate is set for testing in China, Fortune, 2020, https:/fortune.com/2020/02/03/ coronavirus-vaccine-testing-in-china/, Accessed 28 Feb 2020. 
[102]Park A, Inside the Company That's Hot-wiring Vaccine Research in the Race to Combat the Coronavirus, Time, 2020, https://time. com/5775784/coronavirus-vaccine-research/, Accessed 28 Feb 2020.

[103]Smith J. CureVac bids to develop the first mRNA coronavirus vaccine, 2020, https://www.labiotech.eu/medical/curevac-coron avirusoutbreak-cepi/, Accessed 28 Feb 2020.

[104]Y. Cao, B. Su, X. Guo, W. Sun, Y. Deng, L. Bao, Q. Zhu, X. Zhang, Y. Zheng, C. Geng, X. Chai, R. He, X. Li, Q. Lv, H. Zhu, W. Deng, Y. Xu, Y. Wang, L. Qiao, Y. Tan, L. Song, G. Wang, X. Du, N. Gao, J. Liu, J. Xiao, X. Su, Z. Du, Y. Feng, C. Qin, C. Qin, R. Jin and X. S. Xie, Cell, 2020, doi: 10.1016/j.cell. 2020.05.025.

[105]Inovio Pharmaceuticals. Inovio Collaborating with Beijing Advaccine to Advance INO-4800 Vaccine against New Coronavirus in China, 2020, http://ir.inovio.com/news-and-media/ news/press-release-details/2020/Inovio-Collaborating-WithBeiji ng-Advaccine-To-Advance-INO-4800-Vaccine-AgainstNew-Cor onavirus-In-China/default.aspx, Accessed 28 Feb 2020.

[106]WHO guidelines on hand hygiene in health care: first global patient safety challenge, clean care is safer care, Geneva, World Health Organization, 2009, https://apps.who.int/iris/handle/10665/ 44102, Accessed 17 January 2020.

[107]J. Atkinson, Y. Chartier, C.K.P. Silva, P. Jensen, Y. Li, W.H. Seto, editors, Natural ventilation for infection control in healthcare settings. Geneva, World Health Organization, 2009, https:// apps.who.int/iris/handle/10665/44167, accessed 17 January 2020.

[108]World Health Organization. Infection prevention and control of epidemic-and pandemic-prone acute respiratory diseases in health care, https://apps.who.int/iris/bitstream/handle/10665/ 112656/9789241507134_eng.pdf;jsessionid=E733F39B1C7F544 662C2D4A9973664AE? sequence=1, Accessed 17 January 2020.

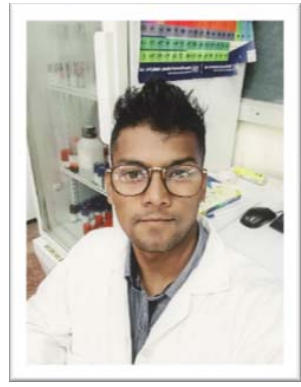

Mr. Viquar Sameer Shaikh is a Research Scholar in the Department of Chemistry, NowrosjeeWadia College Pune-1. He has obtained his B.Sc. (Chemistry) and M.Sc. (Physical Chemistry) from S.P. Pune University Pune. He is researching Pharmaceutical co-crystals at NCL, Pune. He is also researching on the potential inhibitors for COVID-19 using Computer-Aided Drug Design. Also organic synthesis i.e. on Multicomponent reaction towards a Green Chemistry Approach. He has also taken part in various National Conferences and Symposium and presented his research work and also delivered lectures in various lecture competitions and have been a winner.

Dr.G.M.Nazeruddin is presently working as a Professor Emeritus in the Dept. of Chemistry (PG and Research Centre) Abeda Inamdar College, camp, PUNE-411001. He Retired as Principal and Head, Department of Chemistry Poona College of Art, Science and Commerce, Camp, Pune

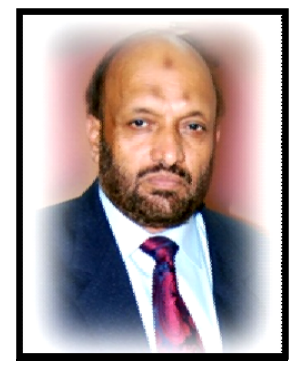

411001. He also had additional charge of Director also of Poona Institute of Management Science and Entrepreneurship (PIMSE) from November 2011 to September 2014 (3 years). He completed his Ph.D. in (1996, NCL) from University of Pune. He has 38 years of Teaching Experience. He also had 33 years of Research Experience. His Research work is in Synthetic Organic Chemistry, Nano particles, Green Chemistry, Medicinal Chemistry. He is a recognized Research Guide for M. Phil and Ph.D. S.P. Pune University, Pune. Nine of his students have already registered for Ph.D. Eight have been awarded the degree and one is about to submit the thesis in due course. Five students have already registered for M.Phil. Five have been awarded the degree. He is a recognized Research Guide Shree JJT University, Rajasthan. Research Paper published in National and International Journals (87).He is Member of the Editorial Board for Four National/ International Journals. He is also a Life Member of 3 various Chemical Societies. He is also a recipient of 4 awards.

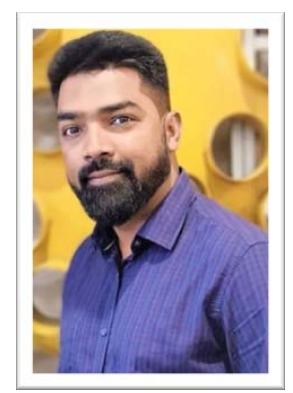

Dr. Yaseen Ismail Shaikh is an Assistant Professor of Organic Chemistry in the Department of Chemistry at Abeda Inamdar Senior College, Camp Pune 411001. He obtained his Ph.D. in 2018 from S.P. Pune University, Pune. He had also qualified National Eligibility Test (NET) with $28^{\text {th }}$ rank in L.S. in "Council of Scientific \& Industrial Research Human Resource-University Grant Commission test for J.R.F. His research focuses on Synthetic Organic Chemistry, Nanotechnology, Computational Chemistry, Medicinal Chemistry, Transition Metal Catalysis, Multicomponent Reactions, and Green Chemistry. He is also a Recognized Research Guide for M.Phil in Chemistry. Affiliated to S.P. Pune University Pune. He has more than 25 scientific publications in International Journals. He has also presented Research papers in various International and National conferences. He is a member of several Chemical Societies. He is also a recipient of the Best Teacher Award.

Dr. Samir Haj Bloukh received his degree in Veterinary Medicine from the University of Faisalabad, Faisalabad, Pakistan in 1977. He also received Postgraduate Diploma in Bacteriology (Microbiology), University of Manchester, UK, 1985 and his Ph.D. in Virology and Serology (Microbiology), University of Manchester, UK, 1991. He began his carrier in the Ministry of Health, Amman, Jordan (1978-1984), where he became the deputy head of the Jordan Vaccine Institute, as well as the head of Diptheria Toxoid Production Unit. 


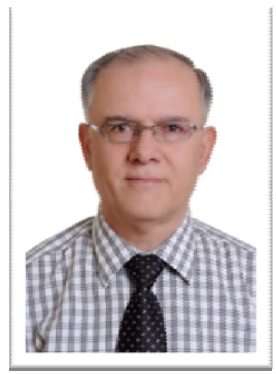

Then he continued with diagnostic Microbiology in the Central Diagnostic Lab of the Ministry of Health, Amman, Jordan. After his PhD., he continued from 1991-1999 as Head of Serology and Virology Department in the Central Diagnostic Laboratory, as well as teaching part-time at Amman University. He received postdoctoral training at the Research Institute For Microbial Diseases, Osaka University, Japan from 1992-1993 in Advanced Microbial Diseases Study. He subsequently moved to the Sustainable Management Development Program of the U.S. Centers for Disease Control and Prevention and The Rollins School of Public Health, Emory University, Atlanta, MI, where received training in Management for International Public Health and another training in Management in 1998. He moved to College of Pharmacy and Health Sciences, Ajman University in 1999 , joined as a faculty member, served as Dean of College of Pharmacy and Health Sciences from 2000-2009, and continues currently as a faculty member and Associate Professor. He has published more than 25 papers, was co-supervisor of 5 research grants, and received several scholarships.

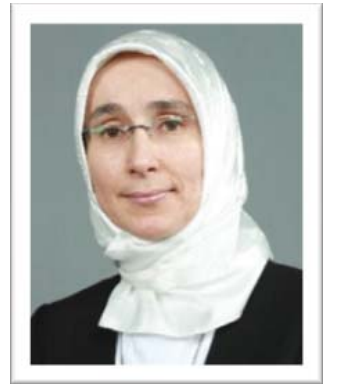

Dr. Zehra Edis received her degree BSc. in 1992 and her MSc. in 1997 in Chemistry from the University of Cologne, Cologne, Germany with the thesis, Investigations on the Synthesis of Fluororganogallium- Compounds". After that, she gained a Ph.D. Scholarship of the Graduiertenkolleg. "Classification of phase transitions in crystalline compounds on account of structural and physical anomalies" from the University of Cologne Germany and received her PhD. in 1999 with the thesis "Polyiodides of 12-Crown-4 Complexes with Alkali cations". She worked as a scientific employee at Akzo Nobel Chemicals in Cologne (Process- and Quality control) and scientific employee at the University of Cologne (Teaching and Lab-Supervision). She worked as Research Intern in Bayer AG, Leverkusen, Germany on the properties of conducting polymers. After that, she joined Ajman University as Part-Time Lecturer in General Chemistry and Laboratory instructor for Engineering and Dentistry in the Ajman University, UAE (2000-2013), later also working additionally as Part-Time Lecturer in Inorganic Chemistry I, II, General Chemistry for Engineering and General Chemistry for Health Sciences, in Sharjah University, UAE. Since February 2014 she is a faculty member and Assistant Professor at Ajman University, UAE. She has published more than 20 papers, was supervisor of 5 research grants, and received one scholarship.

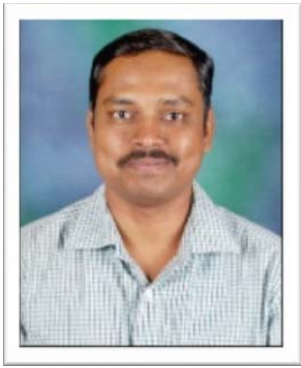

Dr. H. M. Pathan is an Assistant Professor at the Department of Physics, Savtribai Phule Pune University Pune. He obtained his Ph.D. in 2003 from Shivaji University, Kohlapur. He was a visiting scientist (2004-2007) at the Korea Institute of Science and Technology (KIST), South Korea. He has joined the Department of Physics, SavtribaiPhule Pune University Pune in 2008, and established a new research laboratory namely "Advanced Physics Laboratory" and actively engaged in teaching and research. His research focused on the thin-film deposition, nanostructured material for Dye-sensitized solar cells and supercapacitor applications, PEC hydrogen Generation. He has about 205 scientific publications, 04 patents, and 2640 citations. He is a Life Member of the Material Research Society of India. He was a visiting professor at Chonbuk National University Iksan, South Korea.

Publisher's Note: Engineered Science Publisher remains neutral with regard to jurisdictional claims in published maps and institutional affiliations. 